\title{
Evaluation of Different Flax Cultivars in Their Oil, Fatty Acids Protein and Amino Acids and Correlations
}

\author{
Ahmed Abdullah Bakhashwain \\ Arid Land Agriculture Department, Faculty of Meteorology, Environment and Arid Land \\ Agriculture, King Abdulaziz University, Jeddah, Saudi Arabia
}

\begin{abstract}
This study was carried out in the Faculty of Meteorology, Environment and Arid Land Agriculture, King Abdulaziz University to evaluate 7 flax genotypes from different geographical regions concerning their composition from oil and protein contents, fatty acids and amino acids, besides, calculate the correlation coefficients between the fatty acids and also between the amino acids. The main results showed that Verum $\mathrm{cv}$. had the highest oil content and linolenic acid (Omega-3) while Hiera cv. was the highest in meal protein content and most amino acids. The highest amino acid concentration was proline and it ranged from $27.15 \%$ to $30.21 \%$. Linolenic acid (Omega-3) negatively and significantly correlated with Oleic and Linoleic (Omega-6) fatty acids. Lysine amino acid positively and significantly correlated with the amino acids of Glutamine, Aspartic, Leucine, Serine and Isoleucine.
\end{abstract}

Keywords: Amino acid, correlation, fatty acid, flax genotype, oil, protein.

\section{Introduction}

Flax seed (Linum usitatissimum L.) is the sixth largest oilseed crop in the word. Flaxseed has many different components including the main nutrients, is rich in protein and oil besides many other compounds (Green and Marshall, 1981). Flaxseed contains the highest concentrations of $\alpha$-Linolenic acid (Omega-3 fatty acid). Around $60-70 \%$ from its oil is alpha-linolenic acid (Kuijsten, et al., 2005, Whelan and Rust, 2006, Flax Council of Canada, 2008; Bozan and Temeli, 2008). Flaxseed has become very important in human nutrition due to its important components from amino acids and unsaturated fatty acids (El-
Nakhlawy, 1986; El-Lethy, et al.,1987). Flaxseed chemical composition from the fatty acids and amino acids different as a result of the genetic makeup, environment and their interaction (El-Nakhlawy, 2005; Fukumitsu, et al., 2010; Landeta, 2012). Negative correlation was found between protein and oil contents in the flaxseed (El-Nakhlawy, 1986; Leyva et al., 2011).

This investigation aims to study the variation between different flax cultivars from different world geographical regions in their components from protein, oil, amino acids and fatty acids, besides the relation between the amino acids and between the fatty acids. 


\section{Materials and Methods}

This study carried out in Faculty of Meteorology, Environment and Arid Land Agriculture, King Abdulaziz University, Saudi Arabia.

\subsection{The studied flax cultivars}

Pure fresh seed samples of different flax cultivars were used in this study. The studied cvs. were: Giza-8 and Giaz-6 fom Egypt, Nored and L-115 from Canada, Kristina (Germany), Hiera and Verum from Hungary. Randomized complete block design with 4 replication were used to evaluate these cultivars in their components from oil (\%), protein $(\%)$, fatty acids and amino acids. Oil was extracted from the seeds by the method described by A.O.A.C. (1990).

\subsection{Fatty acids determination}

The fatty acid methyl esters (FAMEs) of the studied flaxseed cvs. oils were determined using Gas Chromatography Mass Spectrometer, model Shimadzu GCMSQP2010. Separation was performed on a capillary column DB-5MS $(30 \mathrm{~m} \times 0.32 \mathrm{~m}$, $0.25 \mu \mathrm{m}$ of film thickness). The carrier gas was Helium flow rate of $1.20 \mathrm{ml} / \mathrm{min}$. Temperature of the column was programmed from 70$290^{\circ} \mathrm{C}$ at $15^{\circ} \mathrm{C} / \mathrm{min}$. The injector temperature was $250^{\circ} \mathrm{C}$. Ion source and interface temperature was $200^{\circ} \mathrm{C}$ and $230^{\circ} \mathrm{C}$, respectively. A sample of $1 \mu 1$ in hexane was injected using a split mode, with the split ratio of 1: 50. The mass spectrometer was set to scan in the range of $\mathrm{m} / \mathrm{z} 40-500$ with electron impact (EI) mode of ionization and solvent delay 3 minutes.

\subsection{Amino acids determination}

Flaxseed amino acids were determined using HPLC spectra-physics Analytical, Inc. A0099-600. The analysis was carried out using a gradient of Pico-Tag solvent A and B at $40^{\circ} \mathrm{C}$ and a flow rate of $1 \mathrm{ml} / \mathrm{min}$. Detection of the amino acids was done at $254 \mathrm{~nm}$ wavelength (Steven, et al., 1989).

\subsection{Statistical analysis}

The obtained data of this study were statistically analyzed using the analysis of variance and the means were separated and tested using RLSD at $\mathrm{P} \leq 0.05$. Correlation coefficients were calculated between the fatty acids and also between the amino acids. The statistical analysis was done according to ElNakhlawy (2010) using SAS (SAS, 2006).

\section{Results and Discussion}

\subsection{Oil content}

Statistical analysis of the oil contents in the 7 studied cvs. (Table 1) showed that Verum $\mathrm{cv}$. was the highest in oil content $(39.00 \%)$ followed by 4 cvs. without significant differences between these 4 cvs. oil contents of these 4 cvs. were $36.95 \%, 38.85,36.65 \%$ and $36.65 \%$ for Kristina, L-115, Giza-8 and Nored cvs., respectively. Hiera cv. had the lowest oil content $(33.30 \%)$ compared with the other cvs. The variation in the oil contents between the 7 cvs. might been due to the differences in the genetic makeup of each cultivar and its interaction with the environment (ElNakhlawy, 2005, Fukumitsu, et al., 2010; Landeta, 2012).

\subsection{Fatty acids composition}

The main fatty acids in flaxseed is the unsaturated fatty acids (Oleic, Linoleic and Linolenic acids) as shown in Table 1.

\subsubsection{Total saturated fatty acids}

Total saturated fatty acids (\%) in the studied cvs. oils ranged from $8.22 \%$ in Verum $\mathrm{cv}$. to $11.70 \%$ in Hiera $\mathrm{cv}$. No significant differences were found between Giza-8, Hiera and L-115 cvs. in saturated fatty acids. Also, no significant differences were showed between Giza-6, Kristina and Nored cvs. in 
their contents from total saturated fatty acids (Table 1).

\subsubsection{Unsaturated fatty acids}

As for unsaturated fatty acids, Oleic acid (\%) ranged from $13.73 \%$ in Giza-6 cv. to $20.22 \%$ in L-115 cv. Hiera and Nored cvs. ranked the second without significant difference from each other, followed by Verum cv. (16.25\%) while the lowest Oleic (\%) was found in Giza-6 cv. (13.73\%).

Linoleic acid ranged from $22.57 \%$ in L-115 cv. to $16.20 \%$ in Hiera cv. The 7 cvs. significantly different from each other in Linoleic acid. Linoleic acid was the highest $(\%)$ in the flaxseed oil in all cvs., and ranged

Table 1. Means of oil content (\%), saturated fatty acids (\%), oleic acid (\%), linoleic acid (\%) and linilenic acid (\%) in the seeds of the studied flax cultivars.

\begin{tabular}{|c|c|c|c|c|c|}
\hline \multirow{2}{*}{ Cultivar } & \multirow{2}{*}{$\begin{array}{c}\text { Oil content } \\
(\%)\end{array}$} & $\begin{array}{c}\text { Saturated fatty } \\
\text { acids }\end{array}$ & Oleic acid & Linoleic acid & Linolenic acid \\
\cline { 3 - 6 } & & $11.53 \mathrm{a}$ & $14.82 \mathrm{e}$ & $16.40 \mathrm{e}$ & $58.30 \mathrm{~b}$ \\
\hline Giza-8 & $36.65 \mathrm{~b}^{*}$ & $10.22 \mathrm{~b}$ & $13.73 \mathrm{f}$ & $19.52 \mathrm{~b}$ & $56.82 \mathrm{~d}$ \\
\hline Giza-6 & $34.75 \mathrm{c}$ & $11.70 \mathrm{a}$ & $18.32 \mathrm{~b}$ & $16.20 \mathrm{e}$ & $54.77 \mathrm{e}$ \\
\hline Hiera & $33.30 \mathrm{~d}$ & $8.42 \mathrm{~b}$ & $15.67 \mathrm{~d}$ & $19.27 \mathrm{c}$ & $57.27 \mathrm{c}$ \\
\hline Kristina & $36.95 \mathrm{~b}$ & $9.90 \mathrm{~b}$ & $18.25 \mathrm{~b}$ & $22.47 \mathrm{a}$ & $49.35 \mathrm{f}$ \\
\hline Nored & $36.62 \mathrm{~b}$ & $8.22 \mathrm{c}$ & $16.25 \mathrm{c}$ & $18.63 \mathrm{~d}$ & $58.50 \mathrm{a}$ \\
\hline Verum & $39.00 \mathrm{a}$ & $11.30 \mathrm{a}$ & $20.22 \mathrm{a}$ & $22.57 \mathrm{a}$ & $46.70 \mathrm{~g}$ \\
\hline L-115 & $36.85 \mathrm{~b}$ & & & \\
\hline
\end{tabular}

* Means followed by the same letter are not significantly different according to RLSD at $\mathrm{P} \leq 0.05$.

\subsection{Protein content}

The presented protein means (Table 2) showed that Giza-6 cv. was the highest in protein content $(37.45 \%)$, significantly followed by Hiera cv. $(36.70 \%)$, then Kristina cv. $(34.4 \%)$, while the lowest protein was found in Verum cv. (30.57\%), (Table 1).

\subsubsection{Essential amino acids}

Hiera cv. had the highest concentrations of phenylalanine and leucine amino acids and significantly different from the other cvs. Phenylalanine and Leucine were $2.4 \%$ and $2.55 \%$, respectively in Hiera cv. followed by Kristina for phenylalanine and Giza-6 for leucine. The lowest values of both amino acids from $46.70 \%$ in L-115 to $58.50 \%$ in Verum cv. Significant differences were found between all studied cvs. in Linolenic acid. Linolenic acid (The source of Omega-3) contents were 58.50, $58.30,57.27,56.82,54.77,49.35$ and $46.70 \%$ for Verum, Giza-8, Kristina, Giza-6, Hiera, Nored and L-115 cvs., respectively (Table 1). The promising cvs. in Omega-3 were Verum, Giza-8 and Kristina and can use in human diets. The significant differences in unsaturated fatty acids might been due to the genetic makeup of each cv. and the effects of the environment on this genetic makeup ( $\mathrm{G} x$ E interaction), (El-Nakhlawy, 1986, 1987 and 2005, Leyva, et al., 2011 and Landeta, 2012).

were found in L-115 of both amino acids were found in L-115 cv. and Verum for phenylalanine and leucine acids, respectively as shown in Table 2.

Isoleucine amino acid was highest in both Giza-6 and Hiera cvs. with values of $1.74 \%$ and $1.76 \%$, respectively followed by L-115 cv. $(1.68 \%)$, while the lowest concentrations were found in Kristina and Verum cvs. with values of $1.50 \%$ and $1.52 \%$, respectively (Table 2 ). L-115 cv. seed meal protein had the highest (\%) from Threonine (1.46\%) followed by Giza-8 (1.37\%) then Nored (1.22\%) and Verum cv. (1.21\%), while Giza-6 was the lowest cv. in Threonine amino acid (1.06\%). Lysine amino acid concentrations ranged from 
$1.35 \%$ in Verum cv. to $1.67 \%$ in Nored cv. and no significant differences between Nored, Hiera and Giza-8 cvs. (Table 2).

Concerning Methionine amino acid, the data of Table (2) showed that both Giza- 8 and Giza-6 were the highest in Methionine 0.82\% and $85 \%$, respectively followed by $\mathrm{L}-115$ $(0.73 \%)$, while the lowest values were $0.55 \%$ and $0.52 \%$ in Kristina and Nored cvs., respectively. Hiera and Giza-6 cvs. had the highest Valine amino acid with values $0.42 \%$ and $0.40 \%$, respectively followed by both Nored $(0.36 \%)$ and L-115 $(0.38 \%)$, while the lowest cvs. in Valine amino acid were Kristina and Nored cvs. as shown in Table (2). The data of the essential amino acids in the 7 cvs. cleared that Hiera cv. was the highest cv. in Phenylalanone, Leucine, Isoleucine, Lysine and Valine amino acids, hence, Hiera was the highest in 5 essential amino acids from the 7 essential amino acids found in flaxseed meal protein of the studied cvs. The second cv. in essential amino acids concentrations was Giza$6 \mathrm{cv}$. , which it was the highest in Isoleucine, Methionine and Valine amino acids, besides in crude protein also (Table 2 ).

Table 2. Means of seed protein (\%) and the essential amino acids in the seed protein of the studied Flaxseed cultivars.

\begin{tabular}{|c|c|c|c|c|c|c|c|c|}
\hline \multirow{2}{*}{ Cultivar } & \multirow{2}{*}{$\begin{array}{c}\text { Protein } \\
\text { Content } \\
(\%)\end{array}$} & \multicolumn{7}{|c|}{ Mean of (\%) essential amino acids } \\
\cline { 5 - 10 } & Phenylalanine & Leucine & Isoleucine & Threonine & Lysine & Methionine & Valine \\
\hline Giza-8 & $32.50 \mathrm{~d}^{*}$ & $2.24 \mathrm{~d}$ & $2.38 \mathrm{c}$ & $1.60 \mathrm{c}$ & $1.37 \mathrm{~b}$ & $1.64 \mathrm{ab}$ & $0.82 \mathrm{a}$ & $0.32 \mathrm{c}$ \\
\hline Giza-6 & $37.45 \mathrm{a}$ & $2.19 \mathrm{e}$ & $2.45 \mathrm{~b}$ & $1.74 \mathrm{a}$ & $1.06 \mathrm{e}$ & $1.62 \mathrm{~b}$ & $0.85 \mathrm{a}$ & $0.40 \mathrm{a}$ \\
\hline Hiera & $36.70 \mathrm{~b}$ & $2.42 \mathrm{a}$ & $2.55 \mathrm{a}$ & $1.76 \mathrm{a}$ & $1.14 \mathrm{~d}$ & $1.67 \mathrm{a}$ & $0.64 \mathrm{c}$ & $0.42 \mathrm{a}$ \\
\hline Kristina & $34.45 \mathrm{c}$ & $2.37 \mathrm{~b}$ & $2.25 \mathrm{~d}$ & $1.50 \mathrm{~d}$ & $1.14 \mathrm{~d}$ & $1.51 \mathrm{c}$ & $0.55 \mathrm{~d}$ & $0.27 \mathrm{~d}$ \\
\hline Nored & $31.63 \mathrm{e}$ & $2.18 \mathrm{e}$ & $2.40 \mathrm{c}$ & $1.63 \mathrm{c}$ & $1.22 \mathrm{c}$ & $1.67 \mathrm{a}$ & $0.52 \mathrm{~d}$ & $0.26 \mathrm{~d}$ \\
\hline Verum & $30.57 \mathrm{f}$ & $2.31 \mathrm{c}$ & $1.35 \mathrm{f}$ & $1.52 \mathrm{~d}$ & $1.21 \mathrm{c}$ & $1.35 \mathrm{~d}$ & $0.67 \mathrm{c}$ & $0.36 \mathrm{~b}$ \\
\hline L-115 & $32.47 \mathrm{~d}$ & $2.05 \mathrm{f}$ & $1.43 \mathrm{e}$ & $1.68 \mathrm{~b}$ & $1.46 \mathrm{a}$ & $1.63 \mathrm{ab}$ & $0.73 \mathrm{~b}$ & $0.38 \mathrm{~b}$ \\
\hline
\end{tabular}

* Means followed by the same letter are not significantly different according to RLSD at $\mathrm{P} \leq 0.05$.

\subsubsection{Semi essential amino acids}

Argenine and Hestidine amino acids were the two semi essential amino acids were found in the flaxseed meal proteins. Hiera cv. had the highest values in both amino acids with values of $4.73 \%$ and $1.51 \%$, respectively followed by Giza-6 (1.45\% and $1.43 \%$, respectively), while the lowest values were found in Nored and L115 cvs. for Argenine (4.18\% and 4.17\%, respectively) and Kristina and Verum cvs. for Hestidine $(1.17 \%$ and $1.15 \%$, respectively as shown in Table 3.

\subsubsection{Non essential amino acids}

The presented data of Table (3) indicated that 8 non essential amino acids were detected in the flaxseed meal protein of the $7 \mathrm{cvs}$. The 8 amino acids were Proline, Glutamine, Cystine, Asparatic, Serine, Threonine, Alanine and
Glycine. Proline amino acid was the highest amino acid within the flax protein of the $7 \mathrm{cvs}$. Proline amino acid concentrations ranged from $27.15 \%$ in L-115 cv. to $30.21 \%$ in Hiera cv. The $2^{\text {nd }} \mathrm{cv}$. in Proline content was Giza-6 (29.24\%) followed by Verum cv. (28.96\%). Glulamine and Cystine cvs. ranked the $2^{\text {nd }}$ position after Proline amino acid. Glutamine amino acid concentrations ranged from $6.73 \%$ in Hiera cv. to $5.82 \%$ in Kristina cv.

Cystine amino acid concentrations ranged from $6.296 .27 \%$ in Giza-6 and Hiera cvs. respectively to $5.06 \%$ in L-115 cv. Hiera cv. was the highest cv. in all amino acids except Alanine with values of $30.2 \%, 6.73 \%, 6.27 \%$, $3.44 \%, 2.25 \%, 2.16 \%$ and $1.50 \%$ for Proline, Glutamine, Cystine, Asparatic, Serine, Threonine, Alanine and Glycine amino acids, respectively as shown in Table (3). The results 
of the flaxseed meal protein amino acids profile showed that the Hiera cv. was the highest in most amino acids followed by Giza$6 \mathrm{cv}$. The $2 \mathrm{cvs}$. had rich values from protein content, essential amino acids, semi essential amino acids and non essential amino acids compared with the other studied flax cvs. These results were due to the gene composition of these cvs. and their interaction with the growing environmental conditions during the last harvested seasons in Saudi Arabia. These results were confirmed with the results obtained by (El-Nakhlawy, 1986, 1987 and 2005, Leyva et al., 2011 and Landeta, 2012).

Table 3. Means of the semi essential and non-essential amino acids of the protein of the studied Flaxseed cultivars.

\begin{tabular}{|c|c|c|c|c|c|c|c|c|c|c|}
\hline \multirow{2}{*}{ Cultivar } & \multicolumn{2}{|c|}{$\begin{array}{c}\text { Semi essential amino } \\
\text { acids }\end{array}$} & \multicolumn{9}{|c|}{ Means of the non-essential amino acids } \\
\cline { 2 - 12 } & Argenine & Hestidine & Proline & Glutamine & Cystine & Asparatic & Serine & Tyrosine & Alanine & Glycine \\
\hline Giza-8 & $4.24 \mathrm{c}^{*}$ & $1.56 \mathrm{a}$ & $28.82 \mathrm{~d}$ & $6.54 \mathrm{~b}$ & $5.20 \mathrm{~d}$ & $3.23 \mathrm{c}$ & $1.64 \mathrm{~d}$ & $1.45 \mathrm{~b}$ & $2.06 \mathrm{~b}$ & $1.32 \mathrm{c}$ \\
\hline Giza-6 & $4.45 \mathrm{~b}$ & $1.43 \mathrm{~b}$ & $29.24 \mathrm{~b}$ & $6.54 \mathrm{~b}$ & $6.29 \mathrm{a}$ & $3.33 \mathrm{~b}$ & $1.96 \mathrm{~b}$ & $1.52 \mathrm{a}$ & $2.20 \mathrm{a}$ & $1.53 \mathrm{a}$ \\
\hline Hiera & $4.73 \mathrm{a}$ & $1.51 \mathrm{a}$ & $30.21 \mathrm{a}$ & $6.73 \mathrm{a}$ & $6.27 \mathrm{a}$ & $3.44 \mathrm{a}$ & $2.25 \mathrm{a}$ & $1.51 \mathrm{a}$ & $2.16 \mathrm{c}$ & $1.50 \mathrm{a}$ \\
\hline Kristina & $4.28 \mathrm{c}$ & $1.17 \mathrm{~d}$ & $28.64 \mathrm{f}$ & $5.82 \mathrm{e}$ & $6.16 \mathrm{~b}$ & $3.30 \mathrm{~b}$ & $1.10 \mathrm{e}$ & $1.40 \mathrm{c}$ & $1.36 \mathrm{~d}$ & $1.35 \mathrm{c}$ \\
\hline Nored & $4.18 \mathrm{~d}$ & $1.24 \mathrm{c}$ & $28.74 \mathrm{e}$ & $5.95 \mathrm{~d}$ & $5.33 \mathrm{c}$ & $3.15 \mathrm{~d}$ & $1.11 \mathrm{e}$ & $1.31 \mathrm{~d}$ & $1.46 \mathrm{c}$ & $1.44 \mathrm{~b}$ \\
\hline Verum & $4.24 \mathrm{c}$ & $1.15 \mathrm{~d}$ & $28.96 \mathrm{c}$ & $6.04 \mathrm{c}$ & $5.24 \mathrm{~d}$ & $2.88 \mathrm{e}$ & $1.13 \mathrm{e}$ & $1.24 \mathrm{e}$ & $2.07 \mathrm{~b}$ & $1.33 \mathrm{c}$ \\
\hline L-115 & $4.17 \mathrm{~d}$ & $1.44 \mathrm{~b}$ & $27.15 \mathrm{~g}$ & $6.03 \mathrm{c}$ & $5.06 \mathrm{e}$ & $3.16 \mathrm{~d}$ & $1.75 \mathrm{c}$ & $1.46 \mathrm{~b}$ & $2.04 \mathrm{~b}$ & $1.26 \mathrm{~d}$ \\
\hline
\end{tabular}

* Means followed by the same letter are not significantly different according to RLSD at $\mathrm{P} \leq 0.05$.

\subsection{Fatty acids}

\section{Correlation study}

As for in Table (4), the correlation coefficients revealed that positive significant correlation was found between Oleic and Linoleic acids with $\mathrm{r}=+0.47^{*}$, but the correlations between Oleic and Linolenic or Linoleic and Linolenic acids were negative and significant correlations with values of $0.84^{* *}$ and $-0.78^{* *}$. No significant correlations were found between total saturated fatty acids and any unsaturated fatty acids at $\mathrm{P} \leq 0.05$.

Table 4. Correlation coefficients between the fatty acids of the flax oil.

\begin{tabular}{|c|c|c|c|c|}
\hline & $\begin{array}{c}\text { Saturated } \\
\text { Fatty acids }\end{array}$ & $\begin{array}{c}\text { Oleic } \\
\text { acid }\end{array}$ & $\begin{array}{c}\text { Linoleic } \\
\text { acid }\end{array}$ & $\begin{array}{c}\text { Linolenic } \\
\text { acid }\end{array}$ \\
\hline $\begin{array}{c}\text { Saturated } \\
\text { Fatty acids }\end{array}$ & $1.0^{* *}$ & $0.31^{\mathrm{NS}}$ & $0.19^{\mathrm{NS}}$ & $-0.34^{\mathrm{NS}}$ \\
\hline Oleic acid & --- & $1.0^{* *}$ & $0.47^{*}$ & $-0.84^{* *}$ \\
\hline $\begin{array}{c}\text { Linoleic } \\
\text { acid }\end{array}$ & --- & --- & $1.0^{* *}$ & $-0.78^{* *}$ \\
\hline $\begin{array}{c}\text { Linolenic } \\
\text { acid }\end{array}$ & --- & --- & --- & $1.0^{* *}$ \\
\hline
\end{tabular}

${ }^{\mathrm{NS}}$ : not significant at $\mathrm{P} \leq 0.05$.

${ }^{*},{ }^{* *}$ : significant at $\mathrm{P} \leq 0.05$ and $\mathrm{P} \leq 0.01$, respectively.
These results are useful to select the highest in Linolenic acid (Omega-3) by select the lowest genotype in Oleic acid or Linolenic acid, but by selecting the highest cv. in Oleic, the reader can select the highest $\mathrm{cv}$. in Linoleic acid (the source of Omega-6). These findings are more useful in flax breeding for the highest nutrients of Omega-3 and Omega-6.

\subsection{Amino acids}

As for the correlation coefficients between the 17 amino acids in flaxseed meal protein (Table 5) the presented results showed that Proline amino acid positively and significantly correlated with Glycine $\left(0.65^{* *}\right)$, Leucine $\left(0.63^{* *}\right)$, Phenylalanine $\left(0.76^{* *}\right)$, Arogenine $\left(0.79^{* *}\right)$ and Glutamine amino acids $\left(0.48^{* *}\right)$, but negatively correlated with Threonine ($\left.0.62^{* *}\right)$.

Glutamine positively and significantly correlated with the amino acids of Methionone $\left(0.61^{* *}\right)$, Alanine $\left(0.67^{* *}\right)$, Tyrosine $\left(0.65^{* *}\right)$, Lysine $\left(0.44^{* *}\right)$, Hestidine $\left(0.81^{* *}\right)$, Serine $\left(0.54^{* *}\right)$ and Leucine $\left(0.48^{*}\right)$, but negatively 
correlated with Cystine $\left(-0.59^{* *}\right)$. Argenine amino acid positively and significantly correlated with Glycine $\left(0.47^{*}\right)$, Isoleucine $\left(0.63^{* *}\right)$, Serine $\left(0.72^{* *}\right)$, Leucine $\left(0.54^{* *}\right)$, Phenylalanine $\left(0.52^{*}\right)$, but it negatively correlated with Methionine $\left(-0.53^{*}\right)$. The important amino acid in the human diet, Lysine positively and significantly correlated with the amino acids of Glutamine $\left(0.44^{*}\right)$, Asparatic $\left(0.62^{* *}\right)$, Leucine $\left(0.62^{* *}\right)$, Serine $\left(0.79^{* *}\right)$ and Isoleucine $\left(0.52^{*}\right)$ and negatively correlated with Cystine amino acid with $\mathrm{r}=$ $0.54^{*}$.

The results of the amino acids correlations are very important for the flax breeder to select the needed amino acid using the selection for other. Also, the Lysine content in flax protein is low, but by know the correlations with other amino acids, the breeders can improve the Lysine concentration in flaxseed meal (ElNakhlawy, 2005; Leyva, et al., 2011).

Table 5. Correlation coefficients between the amino acids of the flaxseed protein.

\begin{tabular}{|c|c|c|c|c|c|c|c|c|c|}
\hline Amino acids & $\begin{array}{l}\text { Phenyl- } \\
\text { alanine }\end{array}$ & Leucine & Isoleucine & Threonine & Lysine & Methionine & Valine & Argenine & Hestidine \\
\hline Phenyl-alanine & $1.0^{* *}$ & $0.36^{\mathrm{NS}}$ & $-0.24^{\mathrm{NS}}$ & $-0.58^{* *}$ & $-0.28^{\mathrm{NS}}$ & $-0.34^{\mathrm{NS}}$ & $-0.11^{\mathrm{NS}}$ & $0.52^{*}$ & $-0.15^{\mathrm{NS}}$ \\
\hline Leucine & & $1.0^{* *}$ & $0.33^{\mathrm{NS}}$ & $-0.46^{*}$ & $0.36^{\mathrm{NS}}$ & $-0.08^{\mathrm{NS}}$ & $-0.53^{*}$ & $0.54^{* *}$ & $-0.36^{\mathrm{NS}}$ \\
\hline Isoleucine & & & $1.0^{* *}$ & $0.16^{\mathrm{NS}}$ & $0.75^{* *}$ & $-0.03^{\mathrm{NS}}$ & $-0.08^{\mathrm{NS}}$ & $0.63^{* *}$ & $0.52^{*}$ \\
\hline Threonine & & & & $1.0^{* *}$ & $0.15^{\mathrm{NS}}$ & $0.19^{\mathrm{NS}}$ & $0.14^{\mathrm{NS}}$ & $-0.30^{\mathrm{NS}}$ & $0.29^{\mathrm{NS}}$ \\
\hline Lysine & & & & & $1.0^{* *}$ & $0.13^{\mathrm{NS}}$ & $-0.32^{\mathrm{NS}}$ & $0.39^{\mathrm{NS}}$ & $0.70^{* *}$ \\
\hline Methionine & & & & & & $1.0^{* *}$ & $0.70^{* *}$ & $-0.53^{*}$ & $0.64^{* *}$ \\
\hline Valine & & & & & & & $1.0^{* *}$ & $-0.36^{\mathrm{NS}}$ & $0.27^{\mathrm{NS}}$ \\
\hline Argenine & & & & & & & & $1.0^{* *}$ & $0.12^{\mathrm{NS}}$ \\
\hline Hestidine & & & & & & & & & $1.0^{* *}$ \\
\hline \multicolumn{10}{|l|}{ Proline } \\
\hline \multicolumn{10}{|l|}{ Glutamine } \\
\hline \multicolumn{10}{|l|}{ Cystine } \\
\hline \multicolumn{10}{|l|}{ Asparatic } \\
\hline \multicolumn{10}{|l|}{ Serine } \\
\hline \multicolumn{10}{|l|}{ Tyrosine } \\
\hline \multicolumn{10}{|l|}{ Alanine } \\
\hline \multicolumn{10}{|l|}{ Glycine } \\
\hline Amino acids & Proline & Glutamine & Cystine & Asparatic & Serine & Tyrosine & Alanine & Glycine & \\
\hline Phenyl-alanine & $0.76^{* *}$ & $0.24^{\mathrm{NS}}$ & $0.41^{\mathrm{NS}}$ & $-0.15^{\mathrm{NS}}$ & $-0.08^{\mathrm{NS}}$ & $-0.58^{* *}$ & $-0.09^{\mathrm{NS}}$ & $0.58^{* *}$ & \\
\hline Leucine & $0.63^{* *}$ & $0.48^{*}$ & $-0.02^{\mathrm{NS}}$ & $0.67^{* *}$ & $0.46^{*}$ & $0.46^{*}$ & $-0.29^{\mathrm{NS}}$ & $-0.04^{\mathrm{NS}}$ & \\
\hline Isoleucine & $0.23^{\mathrm{NS}}$ & $0.40^{\mathrm{NS}}$ & $-0.33^{\mathrm{NS}}$ & $0.24^{\mathrm{NS}}$ & $0.96^{* *}$ & $0.31^{\mathrm{NS}}$ & $0.18^{\mathrm{NS}}$ & $-0.12^{\mathrm{NS}}$ & \\
\hline Threonine & $-0.62^{* *}$ & $-0.19^{\mathrm{NS}}$ & $-0.44^{*}$ & $-0.11^{\mathrm{NS}}$ & $0.12^{\mathrm{NS}}$ & $-0.03^{\mathrm{NS}}$ & 0.13 & $-0.45^{*}$ & \\
\hline Lysine & $0.09^{\mathrm{NS}}$ & $0.44^{*}$ & $-0.54^{*}$ & $0.62^{* *}$ & $-0.28^{\mathrm{NS}}$ & $0.69^{* *}$ & $-0.03^{\mathrm{NS}}$ & $-0.52^{*}$ & \\
\hline Methionine & $-0.28^{\mathrm{NS}}$ & $0.61^{* *}$ & $-0.77^{* *}$ & $-0.34^{\mathrm{NS}}$ & $-0.01^{\mathrm{NS}}$ & $0.52^{*}$ & $0.78^{* *}$ & $-0.51^{*}$ & \\
\hline Valine & $-0.16^{\mathrm{NS}}$ & $0.41^{\mathrm{NS}}$ & $-0.42^{\mathrm{NS}}$ & $-0.86^{* *}$ & $-0.11^{\mathrm{NS}}$ & $0.11^{\mathrm{NS}}$ & $0.91^{* *}$ & $0.07^{\mathrm{NS}}$ & \\
\hline Argenine & $0.79^{* *}$ & $0.31^{\mathrm{NS}}$ & $0.28^{\mathrm{NS}}$ & $0.21^{\mathrm{NS}}$ & $0.72^{* *}$ & $0.07^{\mathrm{NS}}$ & $-0.17^{\mathrm{NS}}$ & $0.47^{*}$ & \\
\hline Hestidine & $0.04^{\mathrm{NS}}$ & $0.81^{* *}$ & $-0.87^{* *}$ & $0.04^{\mathrm{NS}}$ & $0.61^{* *}$ & $0.80^{* *}$ & $0.54^{* *}$ & $-0.56^{* *}$ & \\
\hline Proline & $1.0^{* *}$ & $0.48^{* *}$ & $0.38^{\mathrm{NS}}$ & $0.02^{\mathrm{NS}}$ & $0.38^{\mathrm{NS}}$ & $-0.03^{\mathrm{NS}}$ & $-0.01^{\mathrm{NS}}$ & $0.65^{* *}$ & \\
\hline Glutamine & & $1.0^{* *}$ & $-0.59^{* *}$ & $-0.19^{\mathrm{NS}}$ & $0.54^{* *}$ & $0.65^{* *}$ & $0.67^{* *}$ & $-0.12^{\mathrm{NS}}$ & \\
\hline Cystine & & & $1.0^{* *}$ & $0.07^{\mathrm{NS}}$ & $-0.35^{\mathrm{NS}}$ & $-0.79^{* *}$ & $-0.60^{\mathrm{NS}}$ & $0.80^{* *}$ & \\
\hline Asparatic & & & & $1.0^{* *}$ & $0.25^{\mathrm{NS}}$ & $0.24^{\mathrm{NS}}$ & $-0.72^{* *}$ & $-0.33^{\mathrm{NS}}$ & \\
\hline Serine & & & & & $1.0^{* *}$ & $0.45^{*}$ & $0.19^{\mathrm{NS}}$ & $-0.09^{\mathrm{NS}}$ & \\
\hline Tyrosine & & & & & & $1.0^{* *}$ & $0.34^{\mathrm{NS}}$ & $-0.63^{* *}$ & \\
\hline Alanine & & & & & & & $1.0^{* *}$ & $-0.09^{\mathrm{NS}}$ & \\
\hline Glycine & & & & & & & & $1.0^{* *}$ & \\
\hline
\end{tabular}




\section{Conclusion}

Viera cv. was the highest cv. in oil content and Linolenic acid (\%) (Omega-3) and the lowest in saturated fatty acids. Hiera cv. was the highest $\mathrm{cv}$. in protein content and most essential, semi essential and non essential amino acids. Proline amino acids ranged from $27.15 \%$ to $30.21 \%$, while Lysine amino acid concentration ranged from $1.35 \%$ to $1.67 \%$. Negative and significant correlation was found between Linolenic acid and Oleic and Linoleic acids. Lysine amino acid positively correlated with the amino acids of Glutamine, Asparatic, Leucine, Serine and Isoleucine.

\section{References}

A.O.A.C. (1990) Official Methods of Analysis, Association of Official Analytical Chemists: Agricultural Chemicals, Contaminants, drugs, $15^{\text {th }}$, Ed. Washington, D.C., USA .

Bozan, B. and Temelli, F. (2008) Chemical composition and oxidative stability of flax, safflower and poppy seed and seed oils, Bioresource Technology, 99: 63546354. DOI: 10.1016/j.biortech.2007.12.009.

El-Lethy, S.R., Ayad, H.S. and Talaat, I.M. (2010) Physiological Effect of Some Antioxidants on Flax Plant (Linum uskatissimum L.), World J. of Agric. Sci., 6 (5): 622-629, ISSN1817-3047.
El-Nakhlawy, F.S. (1986) Performance of flowering, fruiting, seed components and quality of flax, Proc. $2^{\text {nd }}$ Conf. of Agron. Alex. Egypt. Soc. of Crop Sci., pp: 929-939.

El-Nakhlawy, F.S. (1987) Studies on the content and quality of flax oil, Alex. J. Agric. Res., 32: 115-123.

El-Nakhlawy, F.S. (2005) Gene effects controlling the inheritance of yield, oil content and fatty acid composition of flax, JKAU: Met., Env. \& Arid Land Agric., 17: 47-57.

El-Nakhlawy, F.S. (2010) Experimental Design and Analysis in Scientific Research, Sci. Pub. Center, king Abdulaziz University, Jeddah, Saudi Arabia.

Flax Council of Canada (2008) www.flaxcouncil.ca/.

Green, A.G. and Marshall, D.R. (1981) Variation for oil quantity and quality in Linseed (Linum usitatissimum), Australian Journal of Agricultural Research, 32 (4): 599-607.

Kuijsten, A., Arts, I., van't Veer, P. and Hollman, P. (2005) The Relative Bioavailability of Enterolignans in Humans Is Enhanced by Milling and Crushing of Flaxseed, Journal of Nutrition, 135: 2812-2816.

SAS, (2006) SAS Institute Inc., Cary Nc ., USA( Soft Ware Statistical Program).

Steven, A., Cohen, M. and Thomas, L. (1989) Manual of advanced techniques for amino acid analysis, The Pico-Tag Method, Millipore Cooperation. 4189 WM02, Rev., 1, USA.

Whelan, J. and Rust, C. (2006) Innovative dietary sources of n-3 fatty acids. Annu Rev Nutr., 26: 75-103. DOI: 10.1146/annurev.nutr.25.050304.092605. 
تقييم أصناف مختلفة من الكتان في محتواها من الزيت ومحتواه من الأحماض الدهنية

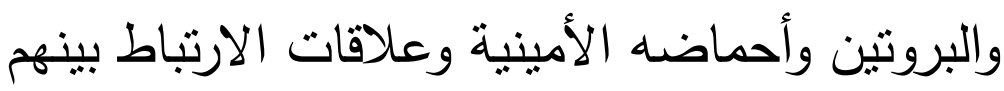

أحمد عبدالله باخشوين

قسم زراعة الدناطق الجافة، كلية الأرصاد والبيئة وزراعة الدناطق الجافة،

جامعة الدلك عبدالعزيز، جدة، المدلكة العربية السعودية

المستخلص. أجريت هذه الدراسة بكلية الأرصاد والبيئة وزراعة المناطق الجافة بجامعة الملك عبدالعزيز بهدف تقييم محتوى سبعة أصناف كتان من مناطق جغرافية مختلفة في العالم في محتواها من الزيت ومحتواه من الأحماض الدهنية والبروتين ومحتواه من الأحماض الأمينية بالإضافة إلى دراسة علاقية فئات الارتباط بين الأحماض الدهنية وكذلك بين الأحماض الأمينية. وقد أوضحت نتائج الدراسة أن الصنف فئه أعطى أعلى محتوى من الزيت في البذور، وأعلى محتوى من الحامض الدهني اللينولينيك (Verum) (أوميجا r)، بينما كان الصنف هييرا (Hiera) هو الأعلى في محتوى البذرة من البروتين، وكذلك في معظم

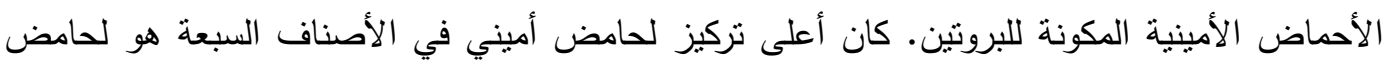

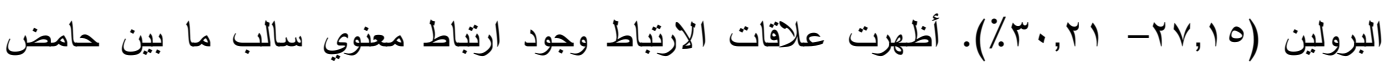
اللينولينيك (أوميجا r)، وكلاً من حامضي الأولييك واللينولييك (أوميجا 7). وقد كان الارتباط بين الحامض الأميني الليثين معنويًا وموجبًا مع كل من الأحماض الأمينية: الجلوتامين والإسبرتيك والليوسين والسيرين والأيزوليوسين.

الكلمات المفتاحبة: حامض أميني، حامض دهني، الكتان، الزيت، البروتين، الارثباط. 